\title{
Emerging Challenges in Nigerian Teaching Profession: Way Forward
}

Oke, Tolutope Idowu (Ph. D)

Department of Educational Foundations, University of Jos. Nigeria

\author{
Ogundele, Michael Olanrewaju (Ph.D) \\ Department of Educational Foundations, \\ University of Jos. Nigeria
}

Doi:10.5901/ajis.2017.v6n1p149

\section{Mainoma, Hauwa'u Muhammad (Ph.D)}

Department of Educational Foundations, Nasarawa State University Keffi Nigeria

\begin{abstract}
s
The paper examined the emerging challenges in Nigerian Teaching profession and way forward. The issues relating to the Teaching Professions, Concepts and the features of a Profession as compare to the teaching in Nigeria are also discussed. The Emerging challenges as discussed in this paper are; Poor Teachers' Salary Structure and Other Remunerations, Deteriorating condition of resources allocation for enhance Teaching-Learning process, Differential Categorization of Teachers, Discriminative Political Interference and Low Degree of Autonomy is Accorded Teaching Profession and solutions were also suggested. It was however concluded that teaching Profession should be accorded high respect through adequate motivation, capacity buildings and ranked similarly with other Professions in Nigeria.
\end{abstract}

Keywords: Emerging challenges, teaching professions and way forward.

\section{Introduction}

It is important to note that the teachers occupied a pivot position in transforming teaching-Learning process for quality education. However, the quality education given in any society has a direct bearing with the quality of her teacher.

In short, the Federal Republic of Nigeria agreed that no nation can rise above the quality of her teachers. It means that teachers play positive role in transforming and shaping any country toward her sustainable national development. The feature of the teacher in the areas of knowledge of the subject matter, professional development and their pedagogical approach make him to be teacher rather than cheaters.

Teachers' Registration Council of Nigeria (2004) defined teaching as the systematic rational and organised process of transforming the acquired knowledge attitude and skills in accordance to the professional principles and practice. The definition therefore indicates that teachers play significant role in guiding and organising the TeachingLearning process to the achievement of goals and objectives.

Also Rakum (2007) also, described teaching as an active systematic process guiding the Learners to acquire all necessary information knowledge and skills that would lead to the desirable positive behavioural change. Teaching therefore, is the process which helps to transform or facilitate effective Teaching-Learning processes that bring about positive behavioural modification and changes.

Teachers are described as people that are directly engaged in guiding, facilitating, instructing the group of learners which turn them to somebody that has a significant change in behaviour. The experiences gained from the TeachingLearning processes enhance effective change in behaviour.

According to Olorundare (2012) Teacher is any person that had undergone approved Professional training in education to the level of capable of imparting Knowledge, Skills, Attitude, and Ability to the Learners which aid their 
behavioural change.

However, Professional teachers can be defined as any person that had acquired Professional knowledge in teaching and be able to use them during the Teaching-Learning processes: A Professional teacher is the only tool that can enhance successful implementation of the educational system. Fareo (2002).

\section{Features of Professional Teacher}

The angle tailor that enhances effectiveness and success of any education level is the teacher. No wonder that Nwachukwu (2004) Stated that "no teacher, no nation". This implies that whatever situation in any country, without considering the teachers, such nation will definitely end up in failure. A professional teacher has the following characteristics according to Yusuf, Afolabi \& Oyetayo (2014)

\subsection{Personal Traits}

These traits are those features which teachers should posses as an individual. Such traits include: sympathy and kindness, fairness and impartial, resourcefulness, patience, good manner, emotional stability, honesty, sense of humour, self control, creativeness, resourcefulness, interpersonal relationship, with the communities and students, model role and community advisers.

Fareo (2002) Described teaching Profession as an occupation or vocation that requires specialised skills, and knowledge through special training with high level of Education, Foundation and Abilities. Teaching is one of the fundamental skills. It is regarded as a systematic ways of guiding individuals and transmitting the basic knowledge, Skills, Abilities and interest that are required for a sustainable development of an individual and society at large. Teaching therefore, aimed at the systematic way of facilitating learning towards embracing individuals. Change in behaviours and to create a compatible mind of individual to society development or modifying individual learners change in behaviours.

However, for individuals to be good teacher such person is expected to posses the following characteristics Vis-àvis; knowledge of subject matter, good planner, good classroom manager, accord interpersonal relationship with the students, the parents and community at large, humbleness, commitment, teaching qualifications, models to the coming generation.

It should be noted that teaching is regarded as a professional career because teaching is like other profession such as Engineering, Medical, Nursing, Lawyers and Journalisms.

\subsection{Acquisition of specific area of qualification}

A Professional teacher should have a specialised area of qualification and such qualification should be acquired form well recognised institutions. The specialised qualification includes: Nigeria Certificate of Education, Diploma in Education, Bachelor in Education (Science or Arts) Master in Education and Doctor of Philosophy in Education. Any person without any of the above is not a teacher since teaching has specialised qualification like any other profession such make teaching job to be profession.

\subsection{Membership of professional association}

Just like any other profession, teaching has professional association where every qualified teacher should belong to such as Nigerian Union of Teachers, Teachers Registration Council, ASUU, National Association of Educational Planning and Administration; the members of qualified teachers to these associations make the teaching to be profession

\subsection{Lengthy Period of Academic and Practical Training}

Before one acquires teaching skills, for instance it takes at least 5 years both practical and theoretical studies before certificated as qualified teacher,

\subsection{Recognition by the Public}

The recognition by the public is based on the nature of the service provided by the profession essentially to humanity. 
These should be self esteem and self satisfaction, which teaching is not an exception.

\subsection{Availability of Ethical Code of Conduct}

All the professions have their ethical code of conduct which guided their operations. Teachers have their dos and don'ts, rules and regulations guiding their existence and activities. The availability of code of conduct however, makes the teaching to be profession.

\subsection{Specified and Regulatory Salary structure}

For any occupation to be regarded as profession there should be salary structure. Teaching has her own salary structure such as: Teacher Salary Structure (TSS). However, in teaching profession any teacher that did not have teaching qualification would not be entitled to Teachers salary Structure.

\subsection{Essential Social Service Provision for the Community}

Like any other profession, teaching provide essential social service like teaching curriculum activities, public enlightenment, participation in community development. These services provision made the teaching to be regarded as profession

\subsection{Dress Code or Identification Uniform for a profession}

When layman sees a lawyer with her dress code or Medical Doctor and Engineer, they can be identified as professions, teaching profession has a dress code of her own which is model dressing and this made them satisfy the criteria of a profession. Ajayi and Ekundayo (2010).

\subsection{Regulatory Body}

There is regulatory body that monitors the conduct of the recognised profession, just like every other profession, teaching has regulatory body called the Teachers Registration Council of Nigeria (TRCN) which regulates the conduct of teachers' operation. Other regularity bodies include: Nigeria Union of Teachers (NUT), Academic Staff Union of University (ASUU). The bodies enable the teachers to speak together in one voice and regulate the conduct of each member and encourage high ethical and moral values that guide the behaviours of all the concern members.

Finally, teaching profession portraits a life process with a good control of knowledge based on the art of teaching all time and we should protect the integrity of teaching by being a repertoire of good ethical conduct and practices in the society.

\section{Emerging Challenges of Teaching Profession in Nigeria}

Teaching profession had been confronted with various challenges; the challenges made the recognition of teaching as a profession a controversy by the members of the society, to the extent that some members of teachers' in training want to make teaching profession as a stepping stone to their different areas of interest. The situation is therefore, attributed to the emerging challenges confronting the operation of teaching as a profession. Other challenges are discussed as follows;

\subsection{Poor Teachers' Salary Structure and Other Remunerations.}

The teacher salaries are too poor and they are poorly remunerated in some cases, teachers' salaries had been misappropriated, embezzled or used to award contract by the disheartening politicians (Abdul kareem (1997). Some of the salaries are not coming and in many States Teachers salary is not paid promptly. The situations however, affect the teachers' moral, productivity and relegate the teachers' effectiveness to the lowest level. 


\subsection{Deteriorating condition of resources allocation for enhance Teaching-Learning process.}

Many schools are established without instructional facilities like: Textbooks, Writing materials, Furniture, Chalks etc. the teachers are working under poor school environment, the school environment are not conducive for effective TeachingLearning process. Many classrooms exist without furniture, window and Doors, many are dilapidated buildings. The situation cannot guarantee the quality education and produce quality product (Oke, 2011). The situation makes the profession to be disrespected among other professions, Gross abuse of Teachers' Ethical Code of Conduct, Teacher Registration Council (TRCN) (2004) outlined the ethical code of conduct that are strictly mandating all teachers in the profession, such as teachers' commitment, honesty, Political engagement, morally and ethically sound etc. However, among teachers today there are series of sexual misconduct, defamation of teachers, high rate of examination misconduct, disloyalty to the profession, embezzlement of school funds, falsification of school records, misappropriation of instructional resources provided for the schools. However, the above ethical and code of conduct lower the integrity of the teaching profession (Ozano 2013).

\subsection{Differential Categorization of Teachers.}

The teachers are categorized into different sub groups, such as Primary School Teachers, Secondary School Teachers, private School Teachers, colleges of Education Lecturers, polytechnic Lectures, and University Lecturers; Even at the polytechnics some lecturers are categorized into Instructors and Technologist. The problem emanated from differential categorization made teachers to see themselves differently and difficult to speak with one voice and fight common sense.

\subsection{Discriminative Political Interference.}

Akindutire (2001) reiterates discriminative political interference in the professionalism of public service in Nigeria: that in Nigeria, there are different national commission such as National Population Commissions, Independent National Electoral Commission (INEC), National Petroleum Commission (NPC), and National Teachers' Institution (NTI), University basic Education Commission (UBEC), National University Commission (NUC), National Education Research and Development Commission (NERDC). It should be noted that the appointment of these commissions have political influence, it is disheartening to note that out of these commission only national universal Basic Education Commission that has sub divisions like state Universal Basic Education, Universal Basic Education Board and local Government Education Universal Basic Education Board. While all other staff of other commissions are paid directly from the Federal Government the National University Basic Education are to be awaiting the State and Local Government contribution to meet up with the teacher's salaries, this is unfair and injustice (Ogundele 2015)

\subsection{Low Degree of Autonomy is Accorded Teaching Profession}

The profession is opened to anybody that has gone to schools, it was observed that the stake holder in the teaching profession did not check the entrance of non-qualified people in teaching; many unqualified people are still found in the teaching profession.

Rakum (2010) observed that in the teaching profession there are HND, B.sc, M.A, Msc, Ph.d without educational background. The author noted that the external influence from the government and influential figure in the country rendered autonomy of teaching profession questionable. The porosity in the entry into the teaching profession constitute high problem, there is absolute and relative size in teaching profession population. The large percentages of Nigerian work force are teachers. The high population however, made the teaching policy implementation controllable. The high population do affect the teachers involvement in the decision making process because the decision makers find it difficult to know which category of the teachers to be involved in the decision making process. The population also gulp highest percentage of the yearly budgeting allocation which is not governmental interest.

\subsection{Teachers are Fragmented into Different Associations}

Teachers in the profession have different association like: Nigerian Union of Teacher (NUT). All Nigeria Conference of Principal of Secondary Schools (ANCOPSS) Vice Chancellors Association of Nigeria University, Science Teachers Association etc. the fragmentation also affects one voice into a situation and it affects togetherness in the profession 
(Ingvasion 1998).

Other challenges are; Lack of Final Awards or Licence Institution in The Teaching Profession Like: Medical, law, and Engineering. So far a teacher has grade II Certificate, or NCE or B.Ed, M.Ed or Ph.D the certificate acquired had qualified him to enter into the teaching profession without necessarily going to the School of Teaching like the Lawyer that must attend Law school, Goodson (2003). There is no prior commitment to the teaching profession, many teachers only use the profession as a stepping stone to other profession they always think of exit or attrition from the profession for better profession which they called "Greener Pasture"

Finally there is no structural background approach for the teaching profession, the teaching profession supposed to have started Teacher Education Programme from Senior Secondary one to SS3 to enable them acquire rudimentary knowledge and aspect of Teachers Education known as Grade II Teachers Certificate. The case is not so instead children that were denied of their choice of courses of admission into Universities just take education course as a last hope "Just to start somewhere because I cannot teach" (Ogundele \& Olaniyi, 2012).

\section{Conclusion and Recommendations}

Due to the fact that teaching profession is confronted with series of challenges, the following recommendations were made:

\subsection{Establishment of National Teachers' Salary Commission}

The Federal Republic of Nigeria should as a matter of urgency establishes only one commission which will see to the payment of teachers' salary and other emoluments. The commission will be charged with the responsibility of handling issue of teacher's salaries from the Primary Education to the Tertiary Education.

\subsection{Promoting Good School Resources Maintenance Culture}

Adequate maintenance culture should be put in place to improve the Educational facilities status to its originality. The provision and maintenance of the available resources devoted to education should be the responsibility of all and sundry like Teachers, Students Philanthropists, Parents and Community.

\subsection{Establishment of quality assurance monitoring body for the teaching profession}

The body should be charged with responsibility of exerting disciplinary actions on any teacher that violate and abuse the teachers' ethical code of conduct. National teachers' forum should be integrated to the teaching profession. The differential treatment and segregation should be avoided among the teachers. The stakeholders in the teaching profession should integrate all activities like seminars, joint consultative meetings and discrepancy in teachers' salaries should be avoided, this will eradicate the fragmentations.

\subsection{Teaching Profession Should Be Free From Excessive Political Interference}

Political interference which leads to the relegation of teachers' integrity should be avoided. National Teachers' Commission should be given equal treatment like other Federal Government Parastatals. The entrance to the teaching profession through teaching or proprietorship should be adequately checked by the Teachers' Registration Council of Nigeria. On no account should untrained person in line of education be assigned to teach in the school system and that any person that wants to establish private schools should acquire teaching background.

This effort will make the relative and absolute size of the people on the teaching profession controllable.

\subsection{Diversification of Teaching Profession}

Teachers' Registration Council of Nigeria (TRCN) in conjunction with Ministry of Education and Faculty of Education, Nigerian Universities should extend the teaching practice exercise of the teachers in training from six- weeks to one year to enable the teachers adequately acquitted with those issues in the teaching profession, the awareness created will aid teacher proficiency, the teachers' Registration council will then prepare the teaching licence for the qualified teachers in 
the school system.

\subsection{Structural Approach to Teacher Education Programme}

There should be structural approach to the teacher's educational programme in Nigeria. This is to say that the National policy on education should refocus that first Nine years of education should focus on Basic Education. From the basic Education the child entry to different areas of specialisation should be structured e.g. some students should go to science College, some to College of Arts and Social Science, some to teachers' education while some will proceed to technical and Vocational College, so at the entry such students will have in mind that they are teachers instead of taking teaching profession to be stepping stone in the nearest future.

\section{References}

Abdulkareem, A.Y. (2007). Prudency and Accountability in Financial of Primary Education in Kwara State, Journal of Education 2(1)5362

Ajayi, I.A \& Ekundayo, H.Y (2010). Contemporary issues in Educational Management. Lagos: Bolabay Press.

Akindutire, I.D (2010). The Teaching Profession Lagos: Universal press

Fareo, J.O (2002). Teaching Profession in Nigeria: issues and problems. Journal of Teachers Education 3(4)62-72

Goodson, I.O (2003) profession Knowledge Professional Lives. Studies in Education Maiden head: Open University Press

Ingvarson, L.A (1998) Professional Development System fit for Profession London Bell Press

Ogundele, M.O (2015). Enhancing teachers Morale for achieving Universal Basic Education goals in Nigeria. Journal of Education Innovators 1(1), 1-6

Ogundele, M.O. \& Olaniyi, J.A (2012). Structural Approach for Effective Teachers Education in Nigeria: International Journal of Educational Research and Mathematics 3(2), 42-50

Oke, T. I (2016). School Location and Facility Utilization as Correlates of Senior Secondary School Students' Academic Achievement in Plateau State: Unpublished Ph. D Thesis. Nasarawa State University Keffi.

Olorundare, J.A (2012). Teaching Professions in Nigeria: Ilorin University Press

Ozano, P.B (2013). Enhancing Teaching Profession in Nigeria. A Historical Perspective. Academic Journal of interdisciplinary Studies $2(5) 51-56$

Rakum, S.A (2007). Nature of Teaching-Learning process in Gimba M. Daramola I.S Mangwvat, B \& Saidu,s (eds) Rudiments of Effective Teaching Jos: University Press

Teachers Registration Council of Nigeria (2004) Teachers Code of Conduct. Abuja NERDC

Yusuf, M.A, Afolabi F.O \& Oyetayo M.D (2014) Professionalization of Teaching through Functional Teachers education, European Scientific Journal 10(4) 107-118 